\section{Grundig om ernæringsepidemiologi}

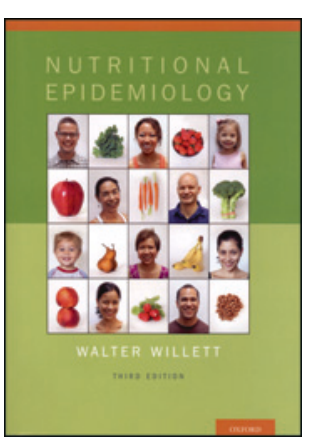

Walter Willett

Nutrition epidemiology

3. utg. 529 s, tab, ill. Oxford: Oxford University

Press, 2013. Pris GBP 45

ISBN 978-0-19-975403-8

Walter Willett, en av verdens ledende ernæringsforskere, har fått med seg et sterkt lag av kolleger til å oppdatere grunnboken i ernæringsepidemiologi. Den fremstår i dag som den mest omfattende læreboken på området. Målgruppen er masterstudenter, stipendiater og forskere innen ernæring og epidemiologi. Annet helsepersonell og beslutningstakere med interesse for ernæring og noe bakgrunn i epidemiologisk metode, er også forventet å ha nytte av den.

Forfatterne gir en god oversikt over forskningsstatus, inkludert metodeutfordringer for standard kostholdsundersøkelser, biokjemiske markører, antropometriske målinger og kartlegging av fysisk aktivitet. Det er også et nytt kapittel om genetikk og kostholdsanalyse. I en serie på fire kapitler anvendes ernæringsepidemiologisk metode på aktuelle problemstillinger, nemlig vitamin A-inntak og lungekreft, fettinntak og brystkreft, kosthold og hjerte- og karsykdom og folatinntak og nevralrørsdefekter.

Betydningen av gode, oppdaterte matvaredatabaser som grunnleggende premiss for ernæringsepidemiologi kunne med fordel vært viet større oppmerksomhet i en så omfattende tekst. Det er også slik at Willetts egen forskning med utstrakt bruk av frekvensspørreskjemaer i store longitudinelle undersøkelser, preger teksten. Men også andre kostholdsmetoder er dekket, og behovet for å videreutvikle eksperimentelle undersøkelser - både for å se på effekten av mat og næringsstoffer på individnivå, i tillegg til effekten av tiltak på populasjonsnivå - blir drøftet.

Boken er skrevet av amerikanere og i første rekke kanskje for amerikanske lesere. Det blir tydelig i kapitlet om politikkutforming («Policy Applications»), hvor alle eksemplene er hentet fra USA. Innholdet, også i dette kapitlet, har imidlertid stor overføringsverdi til europeiske forhold. Jeg anbefaler den også for norske studenter og forskere.

\section{Knut-Inge Klepp}

Avdeling for ernæringsvitenskap

Det medisinske fakultet

Universitetet i Oslo

\section{Ernæringsråd på avveie}

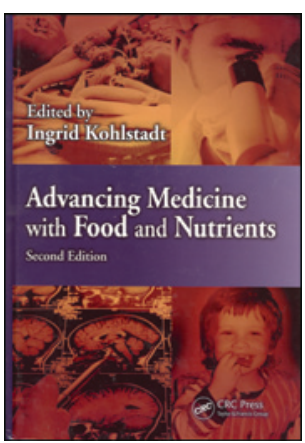

Ingrid Kohlstadt, red.

Advancing medicine with food and nutrients 2. utg. 887 s, tab, ill. Oxon: CRC Press, 2012. Pris GBP 95

ISBN 978-1-4398-8772-1

Ifølge innledningen er målgruppen leger og medisinstudenter som ønsker å få til en endring i livet til sine pasienter og i sin medisinske praksis. Intensjonen til redaktøren og de 71 bidragsyterne er å bedre medikamentell behandling ved riktig kosthold og tilskudd av næringsstoffer. Det gjøres forsøk på dette i de 44 kapitlene, som omfatter behandlingsforslag for både vanlige og mer sjeldne medisinske, nevrologiske og psykiske sykdommer. Hensikten er å skape en «bro» mellom tradisjonell medisin og ernæringsvitenskap. Det har verken redaktøren eller de aller fleste forfatterne lyktes med. Rådene som skal gi en bedre behandling, omfatter alt fra store doser vitaminer og antioksidanter til hvordan en rekke sykdommer forårsaket av asbest, kan diagnostiseres ved hjelp av laserstråler mot mønsterbeskyttede kiropraktikerkart i håndflatene.

Riktignok anbefaler de fleste forfatterne «naturlig» mat og et kosthold med mye frukt, grønnsaker, fisk og flerumettet fett, og de advarer mot et stort konsum av sukker. Dette er jo bra, men boken som helhet er ernæringsråd på avveie, og undergraver tilliten til god, akademisk ernæringsforskning. Man burde egentlig forvente mer av en bok som redigeres av en som er ansatt ved Johns Hopkins University School of Medicine. Jeg kan ikke anbefale den til norske leger og medisinstudenter.

Kaare R. Norum

Avdeling for ernæringsvitenskap

Universitetet i Oslo 